\title{
Isolation and Identification of Flavone Aglycones in Roots of Desmostachya bipinnata Stapf
}

KALPANA P. RAHATE* AND A. RAJASEKARAN ${ }^{1}$

Department Pharmaceutical Chemistry, Smt. Kishoritai Bhoyar College of Pharmacy, Kamptee-441 002, ${ }^{1} \mathrm{KMCH}$ College of Pharmacy, Kovai Estate, Coimbatore-641 048, India 


\begin{abstract}
Roots of Desmostachya bipinnata Stapf are used in the treatment of jaundice and asthma in Indian traditional medicine. Phytochemical investigation of the methanol extract of the roots of this plant led to isolation of three flavonols. The structures of these compounds were assigned on the basis of elemental analysis and spectroscopic evidences as apigenin, luteolin and quercetin, of which apigenin and luteolin were isolated for the first time. The yield of these compounds was $0.0034,0.0026$ and $0.0042 \% \mathrm{w} / \mathrm{w}$, respectively. These findings suggested the possibility that the three flavonoids isolated from the roots of Desmostachya bipinnata could be responsible for the benefits to human health offered by these roots.
\end{abstract}

Key words: Apigenin, Desmostachya bipinnata Stapf, flavonols, luteolin, quercetin

Desmostachya bipinnata (L.) Stapf (family: Poaceae), is an official drug of Ayurvedic Pharmacopoeia. This perennial grass well-known as sacrificial grass is native to northeast and west tropical, northern Africa, countries in the Middle East and temperate and tropical Asia. It is a rhizomatous perennial of dry areas with an extensive system of rhizomes 2-3 mm thick at 20$30 \mathrm{~cm}$ depth. Leaves are coarse, narrow, and tough, up to $50 \mathrm{~cm}$ long, $3-19 \mathrm{~mm}$ wide, often rolled. Ligule is a very short ring of hairs, 1-2 mm. Culms are with glossy yellow leaf sheaths at the base, up to $1 \mathrm{~m}$ high with a conspicuous inflorescence $30-60 \mathrm{~cm}$ long. Spikelets are carried in two dense rows on short branches 2-3 cm long arranged in whorls of 2-4 racemes. Glumes are one-nerved, 1-2 $\mathrm{mm}$ long, lemmas are 2-3 $\mathrm{mm}$ long, often purplish. Seed are ovoid, $1 \mathrm{~mm}$ long, narrow, grooved. Flowering is during August-November and fruiting later in cold season. Roots are bitter, sweet, cooling, diuretic, emollient, galactogogue and astringent, which are used in asthma, jaundice, vitiated conditions of ' $p i t t a$ ' and hyperdipsia ${ }^{[1]}$. It has long been used in various traditions as a sacred plant. It was used by Buddha for his meditation seat when he attained enlightenment ${ }^{[2]}$. During eclipses, its roots are kept in the houses by Hindus in the belief that edible things will not be affected by harmful radiations ${ }^{[3]}$. It is reported that the aerial part exhibit antiulcerogenic ${ }^{[4]}$ and antihelicobacter ${ }^{[5]}$ activity and the whole plant found to be analgesic, antipyretic and antiinflammatory ${ }^{[6]}$. In order to reveal the intrinsic constituents responsible for these major activities of the extract, a few phytochemical investigations and instrumental analyses were carried out. Studies have showed that the flavonols like quercetin, its glycosides and kaempferol and various compounds such as tricin and its glycoside and xanthene had been isolated and identified from the aerial part extracts. However, no flavonoids have

*Address for correspondence

E-mail: rahatekalpana@gmail.com

552 been isolated so far from the root extracts. In the present study, three flavonoids were isolated from the polyphenolic fraction of roots of D. bipinnata, which were characterised using spectroscopic methods and identified as apigenin, luteolin and quercetin, among which apigenin and luteolin have been reported for the first time in this plant. In the present study, isolation, purification and structure elucidation of these compounds were described.

The plant D. bipinnata was collected in the month of October from different regions of Tuticorin in Tamilnadu. The plant was authenticated by theBotanical Survey of India, Coimbatore, India (authentication no: BSI/SRC/5/23/Tech.681). The roots were separated, dried and pulverized. Reference materials apigenin, luteolin were procured from Natural Remedies Pvt. Ltd, India and quercetin from Sigma-Aldrich, St. Louis, MO, USA. Chromatographic column $(600 \times 30$ $\mathrm{mm}$, Borosil, Magnum, India), silica gel (60:20 mesh, Qualigens Fine Chemicals, Mumbai), were used for fractionation. Camag Linomat V applicator, Camag TLC Scanner 3, CAMAG glass twin through chamber, precoated silica gel plate $60 \mathrm{~F} 254(10 \times 5 \mathrm{~cm}$ with $0.2 \mathrm{~mm}$ thickness, E. Merck) were used for highperformance thin-layer chromatography (HPTLC) fingerprinting. Elemental analysis was carried on C-H-N analyser (Elementar Vario EL III). Ultraviolet (UV) measurements were performed on UV double beam spectrophotometer (UV 1800-240 V, Shimadzu). Infrared (IR) spectra were recorded

This is an open access article distributed under the terms of the Creative Commons Attribution-NonCommercial-ShareAlike 3.0 License, which allows others to remix, tweak, and build upon the work non-commercially, as long as the author is credited and the new creations are licensed under the identical terms

Accepted 04 April 2018

Revised 19 August 2017

Received 21 September 2016

Indian J Pharm Sci 2018;80(3):551-556 
in $\mathrm{KBr}$ pellets on a Fourier-transform Infrared spectrophotometer (IR Affinity I, Shimadzu). ${ }^{1} \mathrm{H}$-nuclear magnetic resonance spectroscopy (NMR) and ${ }^{13} \mathrm{C}$-NMR spectra were obtained on a Bruker AV-400 (Biospin) spectrometer using dimethyl sulfoxide-d6 (DMSO-d6) as solvent. Chemical shift was recorded in $\delta(\mathrm{ppm})$ with tetramethylsilane used as an internal reference. All mass spectra (MS) were taken under electronic spray ionization mode on API 2000 MS/MS (AB Sciex, Canada) and analysed on negative mode. In addition, analytical balance (High precision Axis LCGC AGN 204), rotary vacuum evaporator (RV10 Digital, IKA ${ }^{\circledR}$ India Pvt. Ltd.), Soxhlet apparatus (Borosil, Magnum, India), ultra sonicator (CD-4800, Shenzhen Codyson Electrical Co., Ltd., China) were used in this study.

The air-dried and powdered roots of D. bipinnata $(1.4 \mathrm{~kg})$ were extracted with $70 \%$ methanol $(\mathrm{MeOH}$; $2 \times 3$ 1) in a Soxhlet apparatus at $40^{\circ}$. After filtration the extract was evaporated under reduced pressure to render methanol extract (125 g). This extract was initially chromatographed over silica gel column under gradient conditions using benzene, chloroform, ethyl acetate and $\mathrm{MeOH}$ (100:0, 80:20, 60:40, 40:60, 20:80, 0:100). The eluted fractions were collected and monitored on TLC. Similar fractions were pooled together to obtain three major fractions $\left(\mathrm{E}_{1}, \mathrm{E}_{2}\right.$ and $\left.\mathrm{E}_{3}\right)$.

Fraction $\mathrm{E}_{2}(13.6 \mathrm{~g})$ was rechromatographed on silica gel column eluting with chloroform, ethyl acetate and $\mathrm{MeOH}$ mixture $(10: 0,8: 2,6: 4,4: 6,2: 8,0: 10$, gradient) to yield three subfractions. These fractions were purified over Sephadex LH20 with $100 \% \mathrm{MeOH}$ to produce compounds $1(17 \mathrm{mg}, 0.0034 \% \mathrm{w} / \mathrm{w})$, $2(13 \mathrm{mg}, 0.0026 \% \mathrm{w} / \mathrm{w})$ and $3(21 \mathrm{mg}, 0.0042 \% \mathrm{w} / \mathrm{w})$, respectively. Structures of these isolated compounds were established on the basis of elemental analysis and UV, IR, ${ }^{1} \mathrm{HNMR},{ }^{13} \mathrm{CNMR}$, and MS data as well as by comparison with published data. The spectral data were as follows and the structures were shown in fig. 1 .

Compound (1): elements \%: (C 50.7, H 33.03, N<0.5) $\mathrm{C}_{15} \mathrm{H}_{10} \mathrm{O}_{5}$ (molecular weight: 270); MS/MS: m/z 269 (M-H); UVmax (MeOH) nm: 270.4, 337; NaOAc nm: 275.2, 325.8, 391.6; $\mathrm{NaOAc}+\mathrm{H}_{3} \mathrm{BO}_{3} \mathrm{~nm}: 268.8$, 341.2; $\mathrm{AlCl}_{3} \mathrm{~nm}: 276.8,301.4,343.6,381 ; \mathrm{AlCl}_{3}+$ $\mathrm{HCl} \mathrm{nm}: 275.8,301,341.8 ; \mathrm{NaOH} \mathrm{nm}: 275.2,325$, 392.6; IR: $3284 \mathrm{~cm}^{-1}$ : OH, $1649 \mathrm{~cm}^{-1}: \mathrm{C}=\mathrm{O}, 1605,1556$ and $1497 \mathrm{~cm}^{-1}$ : aromatic ring; ${ }^{1} \mathrm{H}$ NMR (DMSO-d, $400 \mathrm{MHz}): \delta 12.9,10.9,10.4(1 \mathrm{H}, \mathrm{s}, 5,7,4$ '-OH), 7.9 (2H, d, J 7.2 Hz, H-2'/H-6'), 6.9 (2H, d, J 7.2 Hz, H-3'/
H-5' ), 6.79 (1H, s, H-3), 6.49 (1H, d, J 2.1 Hz, H-8), 6.2 (1H, J $2.1 \mathrm{~Hz}, \mathrm{H}-6) ;{ }^{13} \mathrm{C}$ NMR (100 MHz, DMSO-d6): $\delta 181.7$ (s, C-4), 164.1 (s, C-2), 163.8 (s, C-7), 161.4 (s, C-5), 161.1 (s, C-4'), 157.4 (s, C-9), 128.5 (d, C-2'/C-6'), 121.1 (s, C-1'), 115.9 (d, C-3'/C-5'), 103.7 (s, C-10), 102.8 (d, C-3), 98.7 (s, C-6), 93.9 (d, C-8).

Compound (2): elements \%: (C 48.09, H 32.76, $\mathrm{N}<0.5)$ $\mathrm{C}_{15} \mathrm{H}_{10} \mathrm{O}_{6}$ (mol. wt. 286); MS/MS: m/z 285 (M-H); UVmax (MeOH) nm: 254.4, 348.2; NaOAc nm: 268.2, $401 ; \mathrm{NaOAc}+\mathrm{H}_{3} \mathrm{BO}_{3} \mathrm{~nm}: 259.8,371.8 ; \mathrm{AlCl}_{3} \mathrm{~nm}: 272.8$, 419.8; $\mathrm{AlCl}_{3}+\mathrm{HCl} \mathrm{nm}: 262.8,274.8,296,359.6296$, 359.6; $\mathrm{NaOH}$ nm: 270.4, 407.8; IR: $3208 \mathrm{~cm}^{-1}$ : $-\mathrm{OH}, 1661 \mathrm{~cm}^{-1}: \mathrm{C}=\mathrm{O}, 1606,1506$ and $1441 \mathrm{~cm}^{-1}$ : aromatic ring; ${ }^{1} \mathrm{H}$ NMR (DMSO-d ${ }_{6}, 400 \mathrm{MHz}$ ): $\delta 12.97(1 \mathrm{H}, \mathrm{s}, 5-\mathrm{OH}), 7.43$ (1H, dd, J 7.8 Hz, H-6'), 7.41 (1H, d, J 2.2 Hz, H-2'), 6.92 (1H, d, J 7.8 Hz, H-5'), $6.66(1 \mathrm{H}, \mathrm{s}, \mathrm{H}-3), 6.47(1 \mathrm{H}, \mathrm{d}, \mathrm{J} 2.2 \mathrm{~Hz}, \mathrm{H}-8), 6.21(1 \mathrm{H}$, d, J $2.2 \mathrm{~Hz}, \mathrm{H}-6) .{ }^{13} \mathrm{C}$ NMR (100 MHz, DMSO d6):

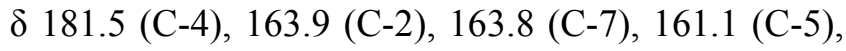
157.3 (C-9), 149.4 (C-4'), 145.5 (C-3'), 121.5 (C-1'), 118.8 (C-6'), 115.8 (C-5'), 113.1 (C-2'), 103.6 (C-10), 102.8 (C-3), 98.6 (C-6), 93.7 (C-8).

Compound (3): elements \%: (C 46.17, H 31.15, $\mathrm{N}<0.5) \mathrm{C}_{15} \mathrm{H}_{10} \mathrm{O}_{7}$ (mol. wt. 302); MS/MS: m/z 301 (M-H); UVmax (MeOH) nm: 256.2, 371.8; NaOAc nm: 279.4, 331.6, 395S; $\mathrm{NaOAc}+\mathrm{H}_{3} \mathrm{BO}_{3} \mathrm{~nm}: 272.8,387$; $\mathrm{AlCl}_{3} \mathrm{~nm}: 278.5,326,438.3 ; \mathrm{AlCl}_{3}+\mathrm{HCl} \mathrm{nm}: 266.7$, 372, 422S; $\mathrm{NaOH} \mathrm{nm}: 329.2$, 426.4; IR: $3277 \mathrm{~cm}^{-1}$ : $-\mathrm{OH}, 1655 \mathrm{~cm}^{-1}$ : $\mathrm{C}=\mathrm{O}, 1610,1522$ and $1449 \mathrm{~cm}^{-1}$ : aromatic ring; ' $\mathrm{HNMR}$ (DMSO-d6, $400 \mathrm{MHz}$ ): $\delta 12.5(1 \mathrm{H}, \mathrm{s}, 5-\mathrm{OH}), 9.4(1 \mathrm{H}, \mathrm{s}, 4$ '-OH $), 7.68(1 \mathrm{H}, \mathrm{d}$, J $2.1 \mathrm{~Hz}, \mathrm{H}-2$ ') 7.55 (1H, dd, J 7.4 Hz, H-6'), 6.9 (1H, d, J 7.4 Hz, H-5'), 6.41 (1H, d, J 2.1 Hz, H-8), 6.19 (1H, d, J $2.1 \mathrm{~Hz}, \mathrm{H}-6) ;{ }^{13} \mathrm{CNMR}(100 \mathrm{MHz}$, DMSO-d6): d 175.8 (C-4), 163.9 (C-7), 160.7 (C-5), 156.1 (C-9), 147.7 (C-3'), 146.7 (C-2), 145.0 (C-4'), 135.7 (C-3), 121.9 (C-1'), 119.9 (C-6'), 115.6 (C-5'), 115.0 (C-2'), 103.0 (C-10), 98.1 (C-6), 93.3 (C-8).

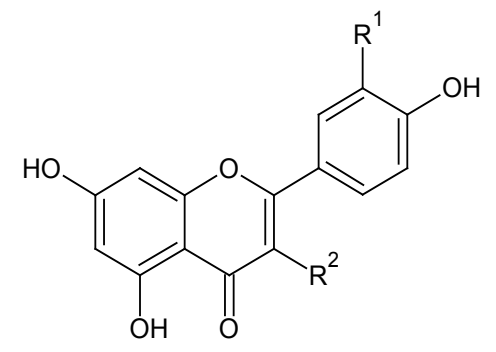

Fig. 1: Structures of flavonoids isolated from Desmostachya bipinnata

Apigenin: $\mathbf{R}^{\mathbf{1}=H}, \mathbf{R}^{2}=\mathbf{H}$; luteolin: $\mathbf{R}^{\mathbf{1}}=\mathbf{O H}, \mathbf{R}^{2}=\mathbf{H}$; quercetin: $\mathbf{R}^{1}=\mathbf{O H}, \mathbf{R}^{2}=\mathbf{O H}$ 
Apigenin (1) was obtained as a pale yellow amorphous powder. The UV spectra (Table 1) in different shift reagents showed the pattern of a 4',5,7-trihydroxy flavone, where the presence of 5-hydroxy group was indicated by $\mathrm{AlCl}_{3}$ spectrum, while the presence of 7-hydroxy group was deduced from $\mathrm{NaOAc}$ spectra. The $\mathrm{NaOH}$ spectrum indicated the presence of free 4'-hydroxy group. The negative atmospheric pressure ionization-tandem mass spectrometry (API-MS/MS) spectrum showed a quasimolecular ion peak $[\mathrm{M}-\mathrm{H}]^{+}$ at $\mathrm{m} / \mathrm{z} 268.9$, corresponding to the molecular formula $\mathrm{C}_{15} \mathrm{H}_{10} \mathrm{O}_{5}$ (fig. 2A), which was supported by elemental analysis ${ }^{[7-9]}$. The IR spectra showed absorption bands for hydroxyl groups $\left(3283.98 \mathrm{~cm}^{-1}\right)$, aromatic ring $\left(1604.8,1555.9,1497.4 \mathrm{~cm}^{-1}\right)$, carbonyl group $\left(1649.4 \mathrm{~cm}^{-1}\right)$ and ketone group $\left(1154.8 \mathrm{~cm}^{-1}\right)$. The ${ }^{1} \mathrm{HNMR}$ spectrum showed two meta coupled aromatic protons at $\delta 6.2(\mathrm{~d}, \mathrm{~J}=2.1 \mathrm{~Hz})$ and $\delta 6.49(\mathrm{~d}, \mathrm{~J}=2.1 \mathrm{~Hz})$, assigned for $\mathrm{H}-6$ and $\mathrm{H}-8$, respectively, confirming a 5,7-disubstituted ring $\mathrm{A}$. The 4'-substituted ring $\mathrm{B}$ was deduced by the appearance of four protons with a typical doublet pattern for 2',6'-H and 3',5'-H at $\delta 7.9$ $(\mathrm{d}, \mathrm{J}=7.2 \mathrm{~Hz})$ and at $\delta 6.9(\mathrm{~d}, \mathrm{~J}=7.2 \mathrm{~Hz})$, respectively. The ${ }^{13} \mathrm{CNMR}$ spectrum indicated the presence of 15 signals corresponding to 15 carbons. Signals for C-7 at $\delta 163.8, \mathrm{C}-4$ ' at $\delta 161.1$ and C-5 at $\delta 161.4$ confirmed the OH-bonded carbons. Thorough study of the homonuclear correlation spectroscopy (COSY) and the heteronuclear multiple quantum coherence (HMQC) spectra helped in full assignment of all protons to their carbon signals. Upon comparison of the spectral data with the earlier reported, the structure of compound 1 (fig. 1) was identified as apigenin, 2-(4-hydroxyphenyl)-5,7-dihydroxy-4-chromenone.

Luteolin (2) was obtained as a cream coloured amorphous powder. The UV spectra in different shift reagents showed the pattern of 3',4',5,7-tetrahydroxy flavone, where the presence of 5-hydroxy group was indicated by $\mathrm{AlCl}_{3}$ spectrum, while the presence of 7-hydroxy group was deduced from $\mathrm{NaOAc}$ spectra. $\mathrm{NaOAc} / \mathrm{H}_{3} \mathrm{BO}_{3}$ spectrum and $\mathrm{AlCl}_{3}$ spectrum gave evidence for the presence of ortho dihydroxy system in ring $\mathrm{B}$. The $\mathrm{NaOH}$ spectrum indicated the presence of free hydroxy groups. The negative API-MS/MS spectrum showed a quasimolecular ion peak $[\mathrm{M}-\mathrm{H}]^{+}$ at $\mathrm{m} / \mathrm{z} 285$ (fig. 2B), corresponding to the molecular formula $\mathrm{C}_{15} \mathrm{H}_{10} \mathrm{O}_{6}$, supported also by elemental analysis. The IR spectra showed absorption bands for hydroxyl groups $\left(3207.65 \mathrm{~cm}^{-1}\right)$, aromatic ring $(1606,1505.6$, $\left.1441.2 \mathrm{~cm}^{-1}\right)$, carbonyl group (1661.05 $\left.\mathrm{cm}^{-1}\right)$ and ketone group $\left(1153.7 \mathrm{~cm}^{-1}\right)$. The ${ }^{1} \mathrm{H}$ NMR spectrum showed two meta coupled aromatic protons at $\delta 6.21$ $(\mathrm{d}, \mathrm{J}=2.2 \mathrm{~Hz})$ and $\delta 6.47(\mathrm{~d}, \mathrm{~J}=2.2 \mathrm{~Hz})$, assigned for $\mathrm{H}-6$ and $\mathrm{H}-8$, respectively, confirming a 5,7-disubstituted ring A. The 3',4'-disubstituted ring B was deduced by the appearance of three protons with a typical doublet pattern for 2',5' and 6'-H at $\delta 7.41(\mathrm{~d}, \mathrm{~J}=2.2 \mathrm{~Hz}), 6.92$ $(\mathrm{d}, \mathrm{J}=7.8 \mathrm{~Hz})$ and at $\delta 7.43(\mathrm{dd}, \mathrm{J}=7.8 \mathrm{~Hz})$, respectively. The ${ }^{13} \mathrm{CNMR}$ spectrum indicated the presence of 15 signals corresponding to 15 carbons. Signals for C-7 at $\delta 163.8, \mathrm{C}-4$ ' at $\delta 149.38, \mathrm{C}-5$ at $\delta 161.1$ and $\mathrm{C}-3$ ' at $\delta 145.47$ confirmed the $\mathrm{OH}$-bonded carbons. Thorough study of the COSY and the HMQC spectra helped in full assignment of all protons to their carbon signals. Upon comparison of the spectral data with the earlier reported, the structure of compound 2 (fig. 1) was identified as luteolin, 2-(3,4-dihydroxyphenyl)5,7-dihydroxy-4-chromenone.

Quercetin (3) was obtained as yellow amorphous powder. The UV spectra in different shift reagents showed the pattern of 3,3',4',5,7-pentahydroxy flavone, where the presence of 5-hydroxy group was indicated by $\mathrm{AlCl}_{3}$ spectrum, while the presence of 7-hydroxy group was deduced from $\mathrm{NaOAc}$ spectra. $\mathrm{NaOAc} / \mathrm{H}_{3} \mathrm{BO}_{3}$ spectrum and $\mathrm{AlCl}_{3}$ spectrum gave evidence for the presence of ortho dihydroxy system in ring $\mathrm{B}$. The $\mathrm{NaOH}$ spectrum indicated the presence of free 3',4'-hydroxy groups. The negative API-MS/MS spectrum showed a quasimolecular ion peak $[\mathrm{M}-\mathrm{H}]^{+}$

TABLE 1: UV SPECTRAL DATA OF FLAVONOIDS 1, 2 AND 3

\begin{tabular}{lcccccc}
\hline \multirow{2}{*}{ Spectrum } & \multicolumn{7}{c}{$\lambda_{\max }$} \\
\cline { 2 - 7 } & \multicolumn{2}{c}{ Flavonoid 1 } & \multicolumn{2}{c}{ Flavonoid 2 } & \multicolumn{2}{c}{ Flavonoid 3 } \\
\cline { 2 - 7 } & \multicolumn{2}{c}{ Band I } & Band II & Band I & Band II & Band I \\
\hline $\mathrm{MeOH}$ & 270.4 & 337 & 254.4 & 348.2 & 256.2 & 371.8 \\
$\mathrm{MeOH}+\mathrm{NaOAC}$ & 275.2 & $325.8,391.6 \mathrm{~S}$ & 268.2 & 401 & 279.4 & $331.6,395 \mathrm{~S}$ \\
$\mathrm{MeOH}+\mathrm{NaOAC}, \mathrm{H}_{3} \mathrm{BO}_{3}$ & 268.8 & 341.2 & 259.8 & 371.8 & 272.8 & 387 \\
$\mathrm{MeOH}+\mathrm{AlCl}_{3}$ & 276.8 & $343.6,381 \mathrm{~S}$ & 272.8 & 419.8 & 278.5 & $326,438.35$ \\
$\mathrm{MeOH}+\mathrm{AlCl}_{3}, \mathrm{HCl}$ & 275.8 & 341.8 & 262.8 & $296,359.6 \mathrm{~S}$ & 266.7 & $372,422 \mathrm{~S}$ \\
$\mathrm{MeOH}+\mathrm{NaOH}$ & 275.2 & $325,392.6 \mathrm{~S}$ & 270.4 & 407.8 & 329.2 & 426.4 \\
\hline
\end{tabular}

S: shoulder 
at $\mathrm{m} / \mathrm{z} 301$ (fig. $2 \mathrm{C}$ ), corresponding to the molecular formula $\mathrm{C}_{15} \mathrm{H}_{10} \mathrm{O}_{7}$, supported also by elemental analysis. The IR spectra showed absorption bands for hydroxyl groups $\left(3276.96 \mathrm{~cm}^{-1}\right)$, aromatic ring (1610, $\left.1522,1449 \mathrm{~cm}^{-1}\right)$, carbonyl group $\left(1655.13 \mathrm{~cm}^{-1}\right)$ and ketone group $\left(1167.8 \mathrm{~cm}^{-1}\right)$. The ${ }^{1} \mathrm{H}$ NMR spectrum showed two meta coupled aromatic protons at $\delta 6.19(\mathrm{~d}$, $\mathrm{J}=2.1 \mathrm{~Hz})$ and $\delta 6.41(\mathrm{~d}, \mathrm{~J}=2.1 \mathrm{~Hz})$, assigned for $\mathrm{H}-6$ and $\mathrm{H}-8$, respectively, confirming a 5,7-disubstituted ring $\mathrm{A}$. The 3',4'-disubstituted ring $\mathrm{B}$ was deduced by the appearance of three protons with a typical doublet pattern for $2^{\prime}, 5^{\prime}$ and $6^{\prime}-\mathrm{H}$ at $\delta 7.68(\mathrm{~d}, \mathrm{~J}=2.1 \mathrm{~Hz})$,

A.
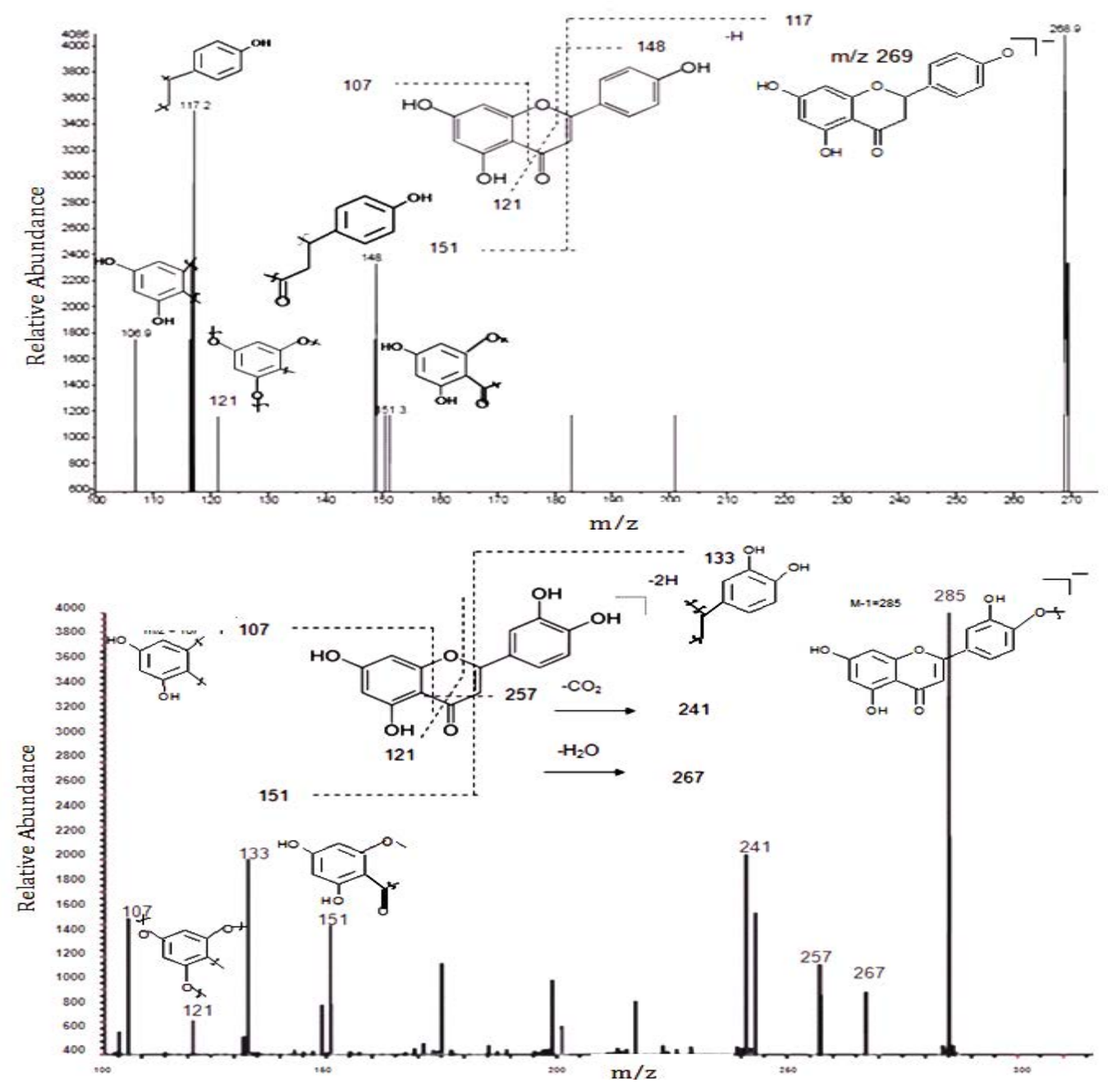

B.

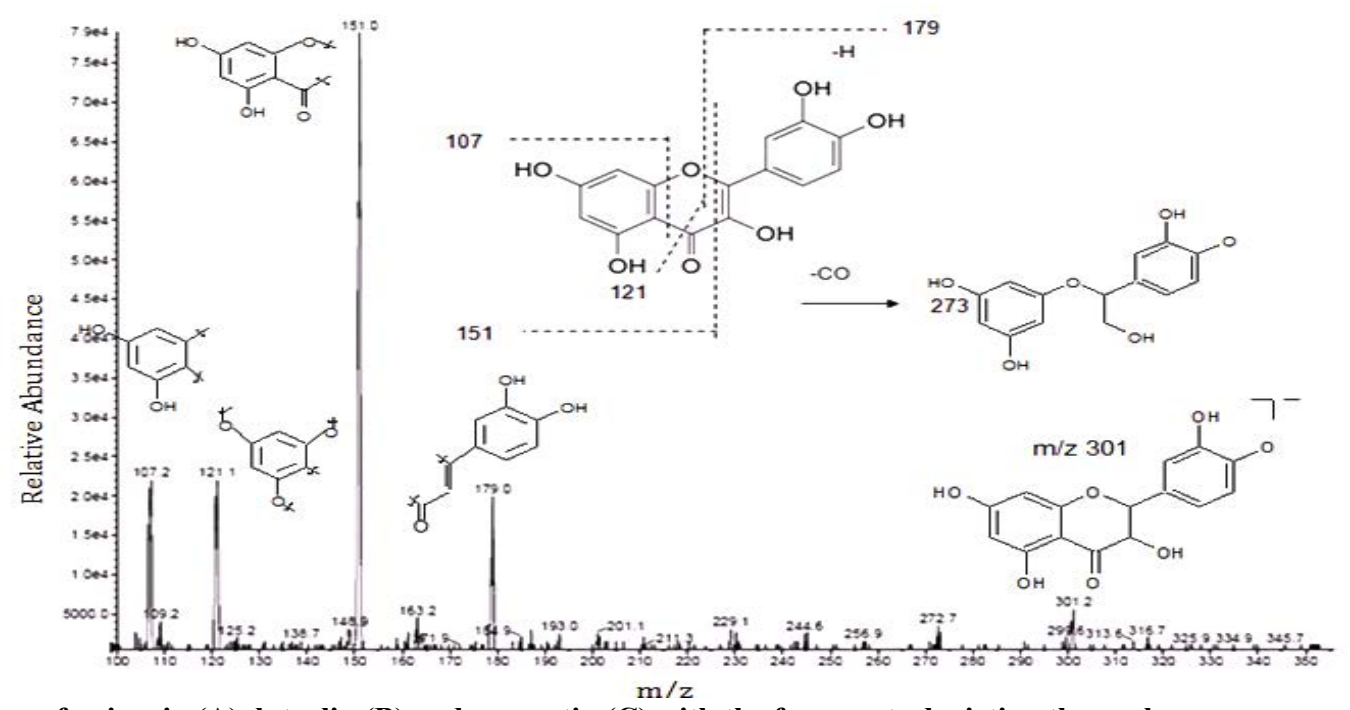

Fig. 2: Mass spectra of apigenin (A), luteolin (B) and quercetin (C) with the fragments depicting the peaks 
$6.9(\mathrm{~d}, \mathrm{~J}=7.4 \mathrm{~Hz})$ and at $\delta 7.55(\mathrm{dd}, \mathrm{J}=7.4 \mathrm{~Hz})$, respectively. The ${ }^{13} \mathrm{CNMR}$ spectrum indicated the presence of 15 signals corresponding to 15 carbons. Signals for C-3 at $\delta 135.68, \mathrm{C}-7$ at $\delta 163.86, \mathrm{C}-3$ ' at $\delta 145, \mathrm{C}-4$ ' at $\delta 147.65$ and C-5 at $\delta 160.67$ confirmed the OH-bonded carbons. Thorough study of the COSY and the HMQC spectra helped in full assignment of all protons to their carbon signals. Upon comparison of the spectral data with the earlier reported, the structure of compound 3 (fig. 1) was identified as quercetin, 2-(3,4dihydroxyphenyl)-3,5,7-trihydroxy-4-chromenone.

The present investigation appears to be the first report of the isolation of apigenin and luteolin from the species D. bipinnata. Till date, the isolation of quercetin and its glycosides, tricin and its glycoside, xanthene and kaempferol were reported from D. bipinnata. These findings also suggested that $D$. bipinnata could be a promising natural source in health-related applications. Previous studies suggested that D. bipinnata was effective antioxidant, in vitro cytotoxic as well as in vitro and in vivo hepatoprotective ${ }^{[10-12]}$. These effects have been attributed to the presence of these flavonols in the plant.

\section{Financial support and sponsorship:}

Nil.

\section{REFERENCES}

1. Warrier PK, Nambiar VPK, Ramankutty C. Indian Medicinal Plants; a Compendium of 500 Species. Hyderabad: Orient Blackswan; 1994.
2. Williams P. Buddhism: Critical Concepts in Religious Studies (Critical Concepts in Religious Studies S.). New York: Routledge; 2006. p. 262.

3. Abdul QP, Hidaytullah A. Ethnobotanical studies of Mahal Kohistan (Khirthar National Park). Pak J Bot 2007;39(7):2301-15.

4. Amani SA, Nawal HM, Derek JM, Gamal AS. Antiulcerogenic Activity of Extract and Some Isolated Flavonoids from Desmostachia bipinnata (L.) Stapf. Rec Nat Prod 2008;2(3):76-82.

5. Ramadan MA, Safwat NA. Antihelicobacter activity of a flavonoid compound isolated from Desmostachya bipinnata. Aust J Basic and Appl Sci 2009;3(3):2270-77.

6. Panda S, Choudhury NSK, Patro VJ, Pradhan DK, Jana GK. Analgesic, Antipyretic and Anti-inflammatory Effect of the Whole Plant Extract of Desmostachya bipinnata Stapf (Poaceae) in Albino Rats. Drug Invention Today 2009;1(2):150-53.

7. Mabry TJ, Markham KR, Thomas MB. The Systematic Identification of Flavonoides. New York, Heidelberg, Berlin: Springer Verlag; 1970.

8. Markham KR. Techniques of Flavonoid Identification. London: Academic Press; 1982.

9. Harborne JB. Flavonoids: Advances in Research since 1986. London: Chapman and Hall; 1994. p. 589-618.

10. Rahate KP, Rajasekaran A, Manju P. Phytochemical evaluation and polyphenolic antioxidant activity of methanolic root extract of Desmostachya bipinnata (Poaceae). J Pharm Res 2011;4(9):3017-20.

11. Rahate KP, Rajasekaran A, Arulkumaran KSG. Potential of Desmostachya bipinnata stapf (Poaceae) root extracts in inhibition of cell proliferation of cervical cancer cell lines. Int J Res Pharm Sci 2012;3(1):5-11.

12. Rahate KP, Rajasekaran A. Hepatoprotection by active fractions from Desmostachya bipinnata stapf (L.) against tamoxifen-induced hepatotoxicity. Indian J Pharmacol 2015;47:311-15. 